\title{
Relationship between the morphogenesis of Italian ryegrass cv. 'BRS Ponteio' with forage and seed production
}

\author{
Relação entre as características morfogênicas do azevém anual \\ cv. 'BRS Ponteio' com a produção de forragem e de sementes \\ Ricardo Pereira da Cunha ${ }^{\mathrm{I}^{*}}$ Carlos Eduardo da Silva Pedroso ${ }^{\mathrm{I}}$ \\ Andréa Mittelmann ${ }^{I I}$ Roberto Caetano de Oliveira ${ }^{I}$ Alberto Bohn ${ }^{I}$ \\ Jéssica Dias Gomes da Silva ${ }^{I}$ Manoel de Souza Maia ${ }^{\mathrm{I}}$
}

\section{ABSTRACT}

This study aims to verify, accurate and precisely, the responses of Italian ryegrass 'BRS Ponteio' cultivar to different frequencies of defoliation for forage production and especially for seed production. For this purpose, a randomized block design experiment with four replications was conducted. Four frequencies of defoliation were applied (zero, one, two, and three) based on the thermal sum, evaluating the rate of leaf appearance (LAR), phyllochron $(P)$, leaf expansion rate (LER), leaf senescence rate (LSR), stems expansion rate (SER), tillering rate (TR), leaf life span (LL), forage production, proportion of leaf blades, stems plus sheaths, senescent material, and inflorescences, as well as seed production. Second defoliation noticeably altered the morphogenic plant responses, reduced expansion rates and leaf appearance, increased rates of tillering and stems expansion. This phenotypic maintained a high seed production and provided a harvest of forage mass 100\% higher than the collected mass in the first cutting. Third defoliation led to an increase of $100 \%$ of the harvested forage mass; however, it caused drastic and negative changes in the morphogenic characteristics and seed yielding.

Key words: Lolium multiflorum Lam., defoliation frequency, leaf expansion rate, leaf senescence rate, phenotypic.

\section{RESUMO}

O presente estudo teve o objetivo de verificar, de forma precisa e detalhada, as respostas da cultivar de azevém anual 'BRS Ponteio', às diferentes frequências de desfolha para a produção de forragem e de sementes. Realizou-se, para tanto, um experimento com delineamento de blocos casualizados com quatro repetições. Foram aplicadas quatro frequências de desfolhas (sem, uma, duas e três) baseando-se no acúmulo térmico, onde se avaliou a taxa de aparecimento de folhas (TApF), o filocrono (F), a taxa de expansão de folhas (TEF), taxa de senescência de folhas (TScF), taxa de expansão dos colmos
(TEC), taxa de perfilhamento (TP), duração de vida da folha $(D V F)$, produção de forragem, proporção de lâminas foliares, colmos mais bainhas, material senescente e inflorescências em cada tratamento, bem como a produção de sementes. A segunda desfolha alterou marcadamente as respostas morfogênicas da planta, reduziu as taxas de expansão e aparecimento de folhas e aumentou as taxas de perfilhamento e de expansão do colmo. Esta plasticidade fenotípica manteve a alta produção de sementes da planta e propiciou a colheita de massa de forragem $100 \%$ superior à massa colhida no primeiro corte. A terceira desfolha propiciou o aumento de 100\% da massa de forragem colhida, todavia, promoveu alterações drásticas e negativas nas caracteristicas morfogenicas e no rendimento de sementes.

Palavras-chave: Lolium multiflorum Lam., frequência de desfolha, taxa de expansão de folhas, taxa de senescência de folhas, fenotipico.

\section{INTRODUCTION}

Development of Brazilian cattle industry depends on the understanding of physiological ecology of forage plants as a base to set an appropriate pasture management (Da SILVA \& NASCIMENTO JUNIOR, 2007). A careful control of time, frequency and intensity of defoliation of the tillers of Italian ryegrass in seed production fields can be crucial to succeed in this production system. On the other hand, the frequency of defoliation at field level is mostly determined from the Julian calendar. Although it is a very practical application technique, sometimes it results in low levels of fodder and seeds production.

\footnotetext{
IPrograma de Pós-graduação em Ciência e Tecnologia de Sementes, Departamento de Fitotecnia, Universidade Federal de Pelotas (UFPel), Campus Universitário s/n, 96010-900, Pelotas, RS, Brasil. E-mail: rpcunha@yahoo.com.br. "Corresponding author.

"Embrapa Gado de Leite/Clima Temperado, Pelotas, RS, Brasil.
} 
Significant errors occur due to not measured sources of variation such, as, for example, climate variations and phenological cycle. Although there are studies regarding the detailed management of defoliation for Italian ryegrass forage production, in a morphogenic level, most studies refer to the common cultivar, which may have important genetic and phenotypic variations. The BRS Ponteio cultivar, recently released, has genetic and phenotypic characteristics well defined in southern Brazil. In spite of the short time since its release, it has a major significance in the southern Brazilian market. Thus, this study aims to verify, accurately and in details, the responses of this cultivar to different frequencies of defoliation for the production of fodder and seeds.

\section{MATERIAL AND METHODS}

The experiment was conducted in an experimental area located in Capão do Leão-RS (31 ${ }^{\circ} 80^{\prime} 00^{\prime \prime} \mathrm{S}$ and $52^{\circ} 40^{\prime} 00^{\prime \prime} \mathrm{W}, 13 \mathrm{~m}$ above sea level). It belongs to the Empresa Brasileira de Pesquisa Agropecuária - Embrapa Clima Temperado/ Estação Terras Baixas. The experiment was held on 04/29/2011, using the Italian ryegrass BRS Ponteio cultivar. The sowing was done in lines, using a direct sowing machine -Semina3 model. The seeding rate was $25 \mathrm{kgha}^{-1}$ of viable, pure seed spaced $20 \mathrm{~cm}$. The experimental soil area was classified as planosol eutric and submitted to conventional tillage (plowing and disking). Soil analysis was performed to correct the acidity and base fertilization. Urea was used (45\% nitrogen) as nitrogen fertilization in coverage, split in two applications. The first $\left(50 \mathrm{kgha}^{-1}\right.$ of nitrogen) was held on $06 / 06 / 2011$, marked by the tillering beginning. The second (60 $\mathrm{kgha}^{-1}$ nitrogen) was held on 09/23/2011, due to temperature and soil moisture, favorable to growth and development of forage grass. The experimental area of $1536 \mathrm{~m}^{2}$ was composed by 16 parts of $88 \mathrm{~m}^{2}$ each, with paths $2 \mathrm{~m}$ width between the two groups of 8 lots each. The experiment included four treatments, arranged in randomized blocks. In order to evaluate the defoliation frequency factor, the following treatments were used: D0 $=$ no defoliation. $\mathrm{D} 1$ = one defoliation, performed when the forage mass reached about $1500 \mathrm{kgDMha}^{-1}$ and the plants had an average height of $15 \mathrm{~cm}$ and a thermal sum of 864 degree-day, on 08/08/2011. D2 = two defoliation, performed with a thermal sum of 420 degree-day, after the first defoliation, when the plants reached about $20 \mathrm{~cm}$, on $09 / 23 / 2011$. D3 = three defoliation performed with a thermal accumulation of 357 degree-day, after the second, when the plants were about $35 \mathrm{~cm}$ high, on $10 / 21 / 2011$. In the postdefoliation condition, the plants were kept at the half-height that they reached in the pre-defoliation condition. So, the plants height, in the post-defoliation condition were 7,10 and $15 \mathrm{~cm}$ for the first, second and third defoliation, respectively. Those conditions were maintained, so that there was an appropriate mass of green leaves after defoliation to favor regrowth. At 45 days after sowing, it was evaluated the morphogenetic characteristics with technique "marked tillers), detailed by CARRÈRE et al. (1997). Calculation of daily heat accumulation was performed by using the equation: $\left[\left(\mathrm{t}^{\circ} \mathrm{Mx}+\mathrm{t}^{\mathrm{o}} \mathrm{Mn}\right) / 2\right]-5 ; \mathrm{t}^{\mathrm{o}} \mathrm{Mx}=$ maximum temperature, $\mathrm{t}^{\circ} \mathrm{Mn}=$ minimum temperature and $5^{\circ} \mathrm{C}=$ the base temperature $(\mathrm{Tb})$ for Italian ryegrass (CONFORTIN et al., 2010). Meteorological data observed in the trial were collected at the Meteorological Station of the Federal University of Pelotas, located next to the experimental area.The forage harvesting was obtained from two samples of $0,1 \mathrm{~m}^{2} \mathrm{lot}^{-1}$, keeping the forage mass described above for each defoliation. Samples were dried in a forced-air oven at $60^{\circ} \mathrm{C}$ for 72 hours, and the results were converted to dry matter $\mathrm{kg}(\mathrm{DM}) \mathrm{ha}^{-1}$. When the seeds reached between 30 and 35\% moisture, the harvesting from eight samples per lot $\left(0,25 \mathrm{~m}^{2}\right.$ each sample), close to the ground, was performed. The first 12 hours drying was done in the shade on covered concrete floor. Drying was completed in a forced air circulation $\left(30^{\circ} \mathrm{C}\right)$ oven. All the drying process was done with the seeds still in the spikelets. Samples were taken to the Laboratório de Sementes Forrageiras no Departamento de Fitotecnia da Faculdade de Agronomia Eliseu Maciel (UFPel), where they were manually threshed and fractionated using sieves. The experimental design was a randomized block with four replications. Analysis of the variance of the data and comparison of means by the Scott-Knott test at $5 \%$ of probability was performed. The statistical program used was the SASM-Agri (CANTERI et al., 2001). The data were also submitted to polynomial regression analysis to describe the variable as a function of time with the same level of significance cited above. Implementation of the polynomial regression statistical analysis used the "Statistical Analysis System for Windows - Winstat" Version 1.0 (MACHADO \& CONCEIÇÃO, 2003).

\section{RESULTS AND DISCUSSION}

The longest leaf lifespan (LL) was measured at 50 days (thermal time $=510$ degree-days) after the sowing (Figure 1a). At that point the leaf

Ciência Rural, v.46, n.1, jan, 2016. 


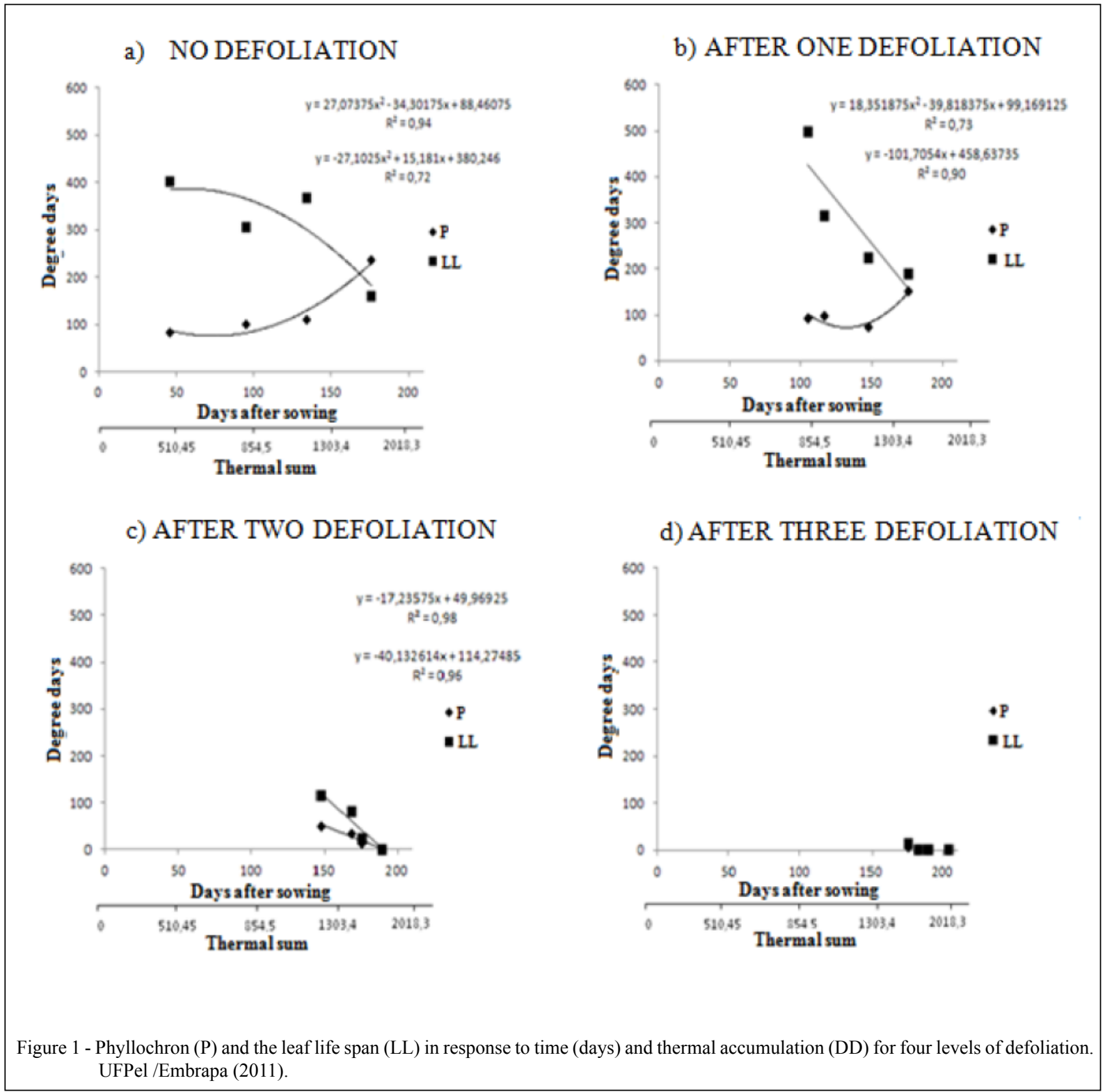

senescence rate (LSR) became significant (Figure 2a). Defoliation could have been done at that time, to avoid losses by senescence. However, it was not possible because the pasture was not able yet, and the plants were not well rooted and the leaf cover was insufficient.The 'BRS Ponteio' showed appropriate conditions to defoliation at 101 days (thermal time= 864 degree-days) after sowing, when the pasture was $15 \mathrm{~cm}$ tall. From day 50 to day 101 there was intense senescence, with a slope similar to the leaf expansion rate (LER) as a function of time, as it is in figure 2a. High senescence can be explained by the high levels of precipitation and low level evaporation.
These are remarkably events in planosol, due to the long period the plant remained under water stress, because of saturated soil and water blade (MAIA \& PRIMO, 1995). Low levels of organic matter and clay verified in planosol, especially in the one where this experiment was conducted (1.4 and 18\% organic matter and clay, respectively), allow a better understanding of the long gap between the sowing and first use of the pasture.

Thus, the variables that determined the need for the first cut at 101 days were the leaf life span (LL) and the rate of leaf senescence (LSR). If defoliation were performed 17 days after, the leaf 


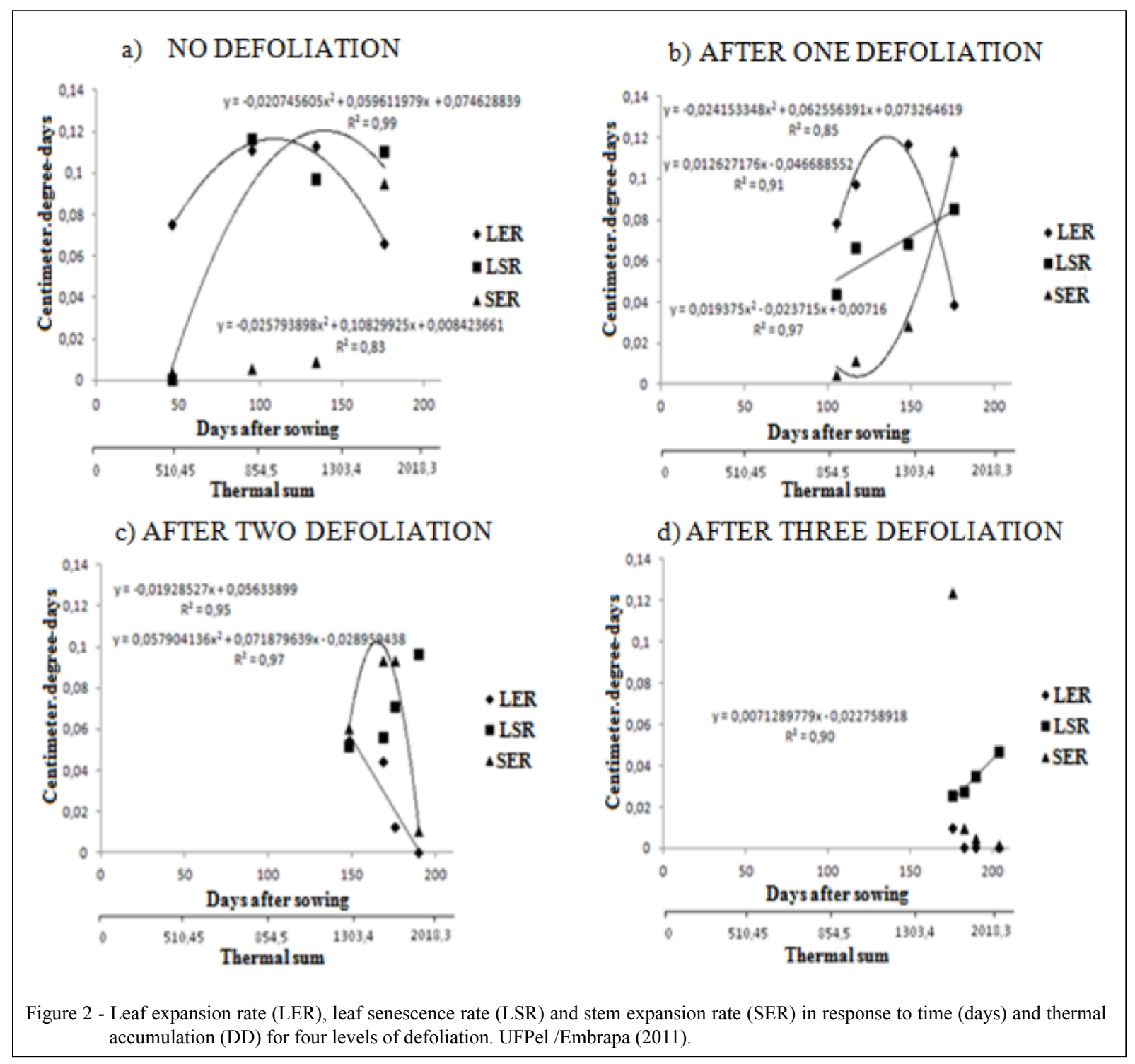

expansion rate (LER) would remain high, but the senescence would exceed the leaf expansion rate. That would result in a negative balance between growth and senescence, affecting the production, quality and structure of the pasture (PARSONS et al., 1988; PEDROSO et al., 2009). By the time of the first defoliation, the expansion rates (LER) and leaves appearance (LAR) were the highest during the production of the crop cycle (Figure $2 \mathrm{a}$ and $3 \mathrm{a}$ ). Those are typical morphogenic characteristics of the growing season. The stem expansion rate (SER) was negligible for the cultivar under research up to the first cut, as a result, the forage harvesting was composed only by leaves (Table 1). CANDIDO et al. (2006) say that a closed canopy, changes the quantity and quality of light, modifying the brightness detected by the phytochrome. Thus, for improving the luminous environment, the internodes lengthen, thereby inhibiting tillering. Such event was not detected for the studied cultivar. Even if $100 \%$ of the light is intercepted by the canopy, just the senescence of older leaves was detected.

Soon after the first cut, lower rates in expansion (LER) and leaf appearance (LAR) in relation to plants in free growing (Figure 2a and $3 b$, respectively) were verified. However, the quadratic models after the first defoliation, for those two variables showed rapid increasing in rates. The amounts were similar to the ones found in not cut plants, probably by conditions of

Ciência Rural, v.46, n.1, jan, 2016. 


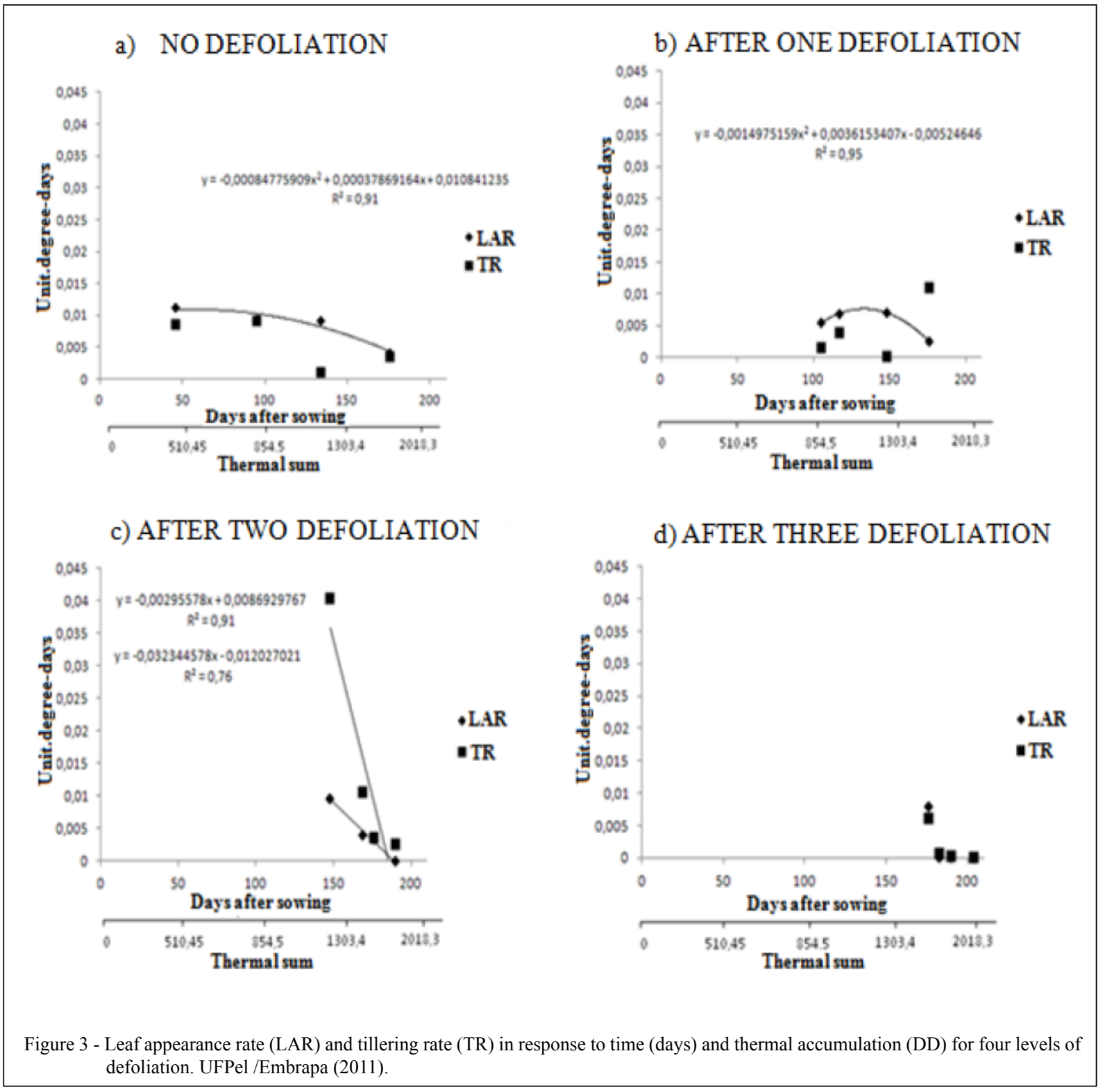

temperature; precipitation and evaporation were more favorable to the culture compared to prior periods. Those best environmental conditions were also, probably important to determine the increase of the leaf life span (LL) and a significant reduction of the senescence after cutting (Figure 1a and 2a, respectively). Both models became linear with intercept quite distant from the values, checked at the same time, for free growing plants. The beginning of the internodes elongation (stem expansion rate - SER) was essential for the second cut (pre-defoliation= $20 \mathrm{~cm}$; after defoliation $=10 \mathrm{~cm}$ ): 46 days or $420 \mathrm{DD}$ after the first. Thus, the forage harvested mass was superior to the first cut, especially due to the higher weight of the stem compared with the leaf. However, because of the reduced stem growth rate - only $49 \%$ of the maximum rate found during the culture cycle, the leaves predominated in relation to the stems, in the harvested forage. Plants in free growth showed significant elongation of the internodes only 140 days after sowing, as seen in figure 2a. Keeping the pasture without defoliation showed a disadvantage, especially excessive leaf senescence. Although, the leaf expansion rate still remained close to the maximum point, indicating the possibility of highperformance forage harvesting in a single cut. It is commonly used for the preparation of hay but could adversely affect seed yield. According to 
Table 1- Italian ryegrass forage production 'BRS Ponteio' cultivar submitted to different managements of defoliation. UFPel/Embrapa (2011).

\begin{tabular}{lcc}
\hline \multirow{2}{*}{ Defoliation } & Forage $\left(\mathrm{kgDMha}^{-1}\right)$ & Seeds $\left(\mathrm{kgha}^{-1}\right)$ \\
\hline Zero & $0 \mathrm{c}$ & $777.70 \mathrm{a}$ \\
One & $517.44 \mathrm{~b}$ & $736.63 \mathrm{a}$ \\
Two & $1102.62 \mathrm{~b}$ & $624.59 \mathrm{a}$ \\
Three & $2473.15 \mathrm{a}$ & $234.41 \mathrm{~b}$ \\
CV $(\%)$ & 17.91 & 6.82 \\
\hline
\end{tabular}

Averages followed by the same letter in the columns do not differ by the Scott-Knott test at a 5\% significance level.

MEDEIROS \& NABINGER (2001), severe cuts reduce the photosynthetic potential of the plants, therefore reducing the seed yielding.

Tillering rate also increased sharply after the second defoliation and application of nitrogen in coverage - the highest rate observed in this study (Figure 3c). The results were similar to those obtained by AHRENS \& De OLIVEIRA (1997), who verified the increasing of tillering, including fertile tillers, in response to cutting and increase of nitrogen fertilization. The environmental conditions favorable to the crop, especially regarding light radiation, as well as the overcoming of the apical dominance by decapitating of the main tillers were determinative in the increasing of the tillering rates soon after the second cut. The balance of the tillering was positive; in other words, the tillering appearance rate was higher than the number of tillers extinct by action of the second cut. However, in about two weeks, an intense internode lengthening occurred (shown in Figure 2c, by the stem expansion rate - SER). Therefore, the reduction of the tillering (sloping high coefficient) at insignificant levels (Figure 3c). At this time, the partition of the assimilated is treated as a priority to the lengthening over the emergence of new tillers (CANDIDO et al., 2006) and the expansion and leaf appearance (with a sloping high coefficient - Figure 2c and 3c, respectively). The sensitivity to the photoperiod and the appearance of the last leaves of the tillers can also explain the sloping of appearance rates and leaf expansion. At the third cut the marked tillers were flourishing, with appearance rates and leaf expansion of almost zero. At the time of the third defoliation, the leaf life span indicates that the time between the second and third defoliation should be close to 100DD to a minimum senescence (Figure 2c). Thus, based on the thermal accumulation of the time, the period between defoliation should be about a week. That is because the leaves prior to inflorescence are smaller and appear more quickly, which explains the reduced values of the phyllochron at those times (Figure 1c). The leaves in this stage last very little, particularly due to their strong drain for the internodes elongation, flowering and seed formation (AHRENS \& De OLIVEIRA, 1997). However, defoliation to harvest only fresh leaves at the end of the cycle usually is not justified in economic terms. In that case, collecting stem and dead material is practically inevitable. It increases the forage mass weight, but in full blooming, the forage quality drops significantly (PEDROSO et al., 2004; PEDROSO et al., 2009). The literature indicates ranges from 300DD and 500DD for the period of Italian ryegrass defoliation, however, such reference when applied at the end of the production cycle of 'BRS Ponteio' cultivar resulted in a significant increase of stem and dead material. However, until the time of the third defoliation, the leaf expansion rate was still positive. The senescence rate hardly varied, although the stem expansion rate was maximum (Figure 2d). If the defoliation was performed later, the rate senescence could be maximum and the expansion leaves rate zero, which further would compromise the forage quality. Therefore, between the second and third defoliation, a major stem growing rates and lower appearance and leaf growing rates were observed (Figures 2 and 3). Thus, the harvest was high in forage mass, $100 \%$ greater than the mass collected in the second cut, however, in the harvested forage, stalks (greater structure weight) were prevailing. The later cutting significantly affected the seed yielding. The reduced tillering rates, appearance and leaf expansion after the third cutting were crucial to the inadequate development of the plant for the seed production. However, the amount of the produced seed was sufficient for establishing the pasture in the following year (BOHN, 2014). Thus, such management would be more suitable for farmers due to the higher forage crop and the amount of seeds, enough for establishing the pasture in the following year by natural reseeding. The second defoliation markedly changed the morphogenic responses of the plant. It reduced the growing and leaf appearance rates and increased the tillering and stems expansion rates. This phenotypic plasticity maintained the high seed production. The first two cuts did not affect the seed yielding so that the similar average seed yielding was $713 \mathrm{kgha}^{-1}$ (Table 1). Higher values than those found by MEDEIROS \& NABINGER (2001), however, similar to that found by CARÁMBULA (1981), in Uruguay, with the cutting by the end of September. 


\section{CONCLUSION}

Performing one defoliation does not change the morphogenesis of the Italian ryegrass 'BRS Ponteio' cultivar along its production cycle. Two harvests allows forage production without compromising seed yeld but three defoliations reduce it.

\section{REFERENCES}

AHRENS, D.C.; DE OLIVEIRA, J.C. Effects of the management of annual ryegrass (Lolium multiflorum Lam.) seeds production. Revista Brasileira de Sementes, v.19, n.1, p.41-47, 1997. Available from: <http://www.abrates.org.br/revista/artigos/1997/ v19n1/artigo08.pdf $>$. Accessed: jun. 23, 2013

BOHN, A. Adubação nitrogenada na produção de biomassa e sementes de azevém em rotação com soja. 2014. $58 \mathrm{f}$ Dissertação (Mestrado em Ciências) - Programa de Pós-Graduação em Ciência e Tecnologia de Sementes, Universidade Federal de Pelotas, Pelotas, RS. Available from: <http:/guaiaca.ufpel.edu. br/bitstream/123456789/1431/1/dissertacao_alberto_bohn.pdf $>$. Accessed: dez. 10, 2014.

CANDIDO, M.J.D. et al. Biomass flow in tanzaniagrass pasture under three resting periods grazed by sheep. Revista Brasileira de Zootecnia, v.35, n.6, p.2234-2242, 2006. Available from: <http:// www.scielo.br/pdf/rbz/v35n6/06.pdf $>$. Accessed: jul. 02, 2013. doi: 10.1590/S1516-35982006000800006.

CANTERI, M.G. et al. SASM-AGRI: system for analysis and mean separation in agricultural assays using Scott-Knott, Tuney and Duncan methods. Revista Brasileira de Agrocomputação, v.1, n.2, p.18-24, 2001. Available from: <http://www.agrocomputacao. deinfo.uepg.br/dezembro 2001/Arquivos/RBAC Artigo 03.pdf> Accessed: feb. 14, 2011

CARÁMBULA, M. Produccion de semilla forrajera. Montevideo: Hemisfério Sur, 1981. 463p.

CARRÈRE, P. et al. Tissue turnover within grass-clover mixed swards grazed by sheep. Methodology for calculating growth, senescence and intake fluxes. Journal of Applied Ecology, v.34, p.333-348, 1997. Available from: <http://www.jstor.org/ stable/2404880?seq=1\#page_scan_tab_contents $>$. Accessed: out. 23, 2010. doi: 10.2307/2404880.

CONFORTIN, A.C.C. et al. Morphogenesis and structure of Italian ryegrass submitted to three grazing intensities. Acta Scientiarum:
Animal Sciences, v.32, p.385-391, 2010. Available from: <http:// periodicos.uem.br/ojs/index.php/ActaSciAnimSci/article/ view/8657>. Accessed: 12. jun, 2011. doi: 10.4025/actascianimsci. v32i4.8657.

DA SILVA, S.C.; NASCIMENTO JÚNIOR, D. Avanços na pesquisa com plantas forrageiras tropicais em pastagens: características morfofisiológicas e manejo do pastejo. Revista Brasilera de Zootecnia, v.36, suppl.0, p.121-138, 2007. Available from: <http://www.scielo.br/scielo.php?pid=S151635982007001000014\&script $=$ sci arttext $>$. Accessed: out. 11, 2011. doi: 10.1590/S1516-35982007001000014.

MACHADO, A.A.; CONCEIÇÃO, A.R. Winstat: sistema de análise estatística para Windows. Pelotas: UFPel/NIA, 2003. Versão 2.0. Available from: <http://www.galileu.esalq.usp.br/vref. php?cod=12>. Accessed: mar. 20, 2012.

MAIA, M.S.; PRIMO, A.T. Cadeia forrageira para a região sul. In: FEDERACITE (Org.). Cadeias forrageiras regionais. Porto Alegre: Caramuru, 1995, p.106-132. Available from: $<$ http://www.scielo.br/scielo.php?script $=$ sci nlinks\&ref $=00014$ 6\&pid $=$ S0101-312220080002000 1300017\&lng=pt $>$. Acessed: out. 12, 2011.

MEDEIROS, R.B.; NABINGER, C. Rendimento de sementes e forragem de azevém-anual em resposta a doses de nitrogênio e regimes de desfolha. Revista Brasileira de Sementes, v.23, n.2, p.245-254, 2001. Available from: <https://scholar.google.com.br/ scholar?q=related:VTAJ1g7SAt4J:scholar.google.com/\&hl=ptBR\&as sdt=0,5>. Accessed: out. 21, 2012.

PARSONS, A.J. et al. Leaf age structure and canopy photosynthesis in rotationally and continuously grazed swards. Grass and Forage Science, v.43, n.1, p.1-14, 1988. Available from: <http://onlinelibrary.wiley.com/ doi/10.1111/j.1365-2494.1988.tb02136.x/epdf>. Accessed: apr. 27, 2013. doi: 10.1111/j.13652494.1988.tb02136.x

PEDROSO, C.E.S. et al. Sheep behavior at the pregnancy anda $t$ the lactation grazing on different phenological stages of annual ryegrass. Revista da Sociedade Brasileira de Zootecnia, v.33, n.5, p.1340-1344, 2004. Available from: <http://www.scielo.br/ scielo.php?script $=$ sci arttext\&pid $=$ S1516-35982004000500028 $>$. Accessed: out. 18, 2011. doi: 10.1590/S1516-35982004000500028.

PEDROSO, C.E.S. et al. Morphogenetic characteristics of pearl millet under rotational grazing with different rest periods Revista Brasileira de Zootecnia, v.38, n.12, p.2311-2319, 2009. Available from: <http://www.scielo.br/scielo.php?pid=S1516 35982009001200004\&script=sci_arttext $>$. Accessed: out. 18, 2011. doi: 10.1590/S1516-35982009001200004. 